\title{
Transformation of Soil Microbial Community Structure and Rhizoctonia-Suppressive Potential in Response to Apple Roots
}

\author{
Mark Mazzola
}

USDA Agricultural Research Service, Tree Fruit Research Laboratory, 1104 N. Western Avenue, Wenatchee, WA 98801. Accepted for publication 20 July 1999.

\begin{abstract}
Mazzola, M. 1999. Transformation of soil microbial community structure and Rhizoctonia-suppressive potential in response to apple roots. Phytopathology 89:920-927.

Changes in the composition of soil microbial communities and relative
disease-suppressive ability of resident microflora in response to apple
cultivation were assessed in orchard soils from a site possessing trees
established for 1 to 5 years. The fungal community from roots of apple
seedlings grown in noncultivated orchard soil was dominated by isolates
from genera commonly considered saprophytic. Plant-pathogenic fungi in
he genera Phytophthora, Pythium, and Rhizoctonia constituted an increas-
ng proportion of the fungal community isolated from seedling roots with
ncreasing orchard block age. Bacillus megaterium and Burkholderia ce-
pacia dominated the bacterial communities recovered from noncultivated
soil and the rhizosphere of apple seedlings grown in orchard soil, re-
spectively. Populations of the two bacteria in their respective habitats de-
clined dramatically with increasing orchard block age. Lesion nematode

populations did not differ among soil and root samples from orchard blocks of different ages. Similar changes in microbial communities were observed in response to planting noncultivated orchard soil to five successive cycles of 'Gala' apple seedlings. Pasteurization of soil had no effect on apple growth in noncultivated soil but significantly enhanced apple growth in third-year orchard block soil. Seedlings grown in pasteurized soil from the third-year orchard block were equal in size to those grown in noncultivated soil, demonstrating that suppression of plant growth resulted from changes in the composition of the soil microbial community. Rhizoctonia solani anastomosis group 5 (AG 5) had no effect on growth of apple trees in noncultivated soil but significantly reduced the growth of apple trees in soil from third-year orchard soil. Changes in the ability of the resident soil microflora to suppress $R$. solani AG 5 were associated with reductions in the relative populations of Burkholderia cepacia and Pseudomonas putida in the rhizosphere of apple.
\end{abstract}

The composition of microbial communities colonizing the plant rhizosphere is influenced in large part by soil type (12), with the plant having a further selective influence $(5,13,22)$. Successional changes in the composition of rhizosphere microflora occur in response to alterations in root physiology and microbial competition (17). In agricultural systems, short-term successive plantings of a crop in the same ground generally result in decreased yields due to increased incidence of soilborne diseases. However, in some annual cropping systems, extended crop monoculture induces a spontaneous reduction in specific soilborne diseases and increased yields. The decline in disease severity observed during extended crop monoculture is believed to result from selection of a microbial community that is suppressive toward certain soilborne plant pathogens $(3,24)$.

Although changes in microbial community structure in response to annual crops and the impacts on plant growth have received considerable attention (13-15), there has been an absence of studies on the impacts of perennial crops on the composition of soil microbial populations and the resulting impacts on plant growth. In the production of perennial tree fruit and nut crops, the soil environment remains physically undisturbed for as long as several decades. However, it seems likely that extensive modification of soil microbial communities occurs during this period, as evidenced by the fact that, although the previous crop performed well, trees of the same species planted later on the same sites typically grow poorly. Sterilization of soils results in dramatically improved tree growth $(1,4)$.

Corresponding author: M. Mazzola; E-mail address: mazzola@tfrl.ars.usda.gov

Publication no. P-1999-0826-02R

This article is in the public domain and not copyrightable. It may be freely reprinted with customary crediting of the source. The American Phytopathological Society, 1999.
Additional keywords: apple replant disease.
Difficulty in establishing perennial fruit and nut tree orchards on sites previously occupied by the same species has been termed replant disease. In general, a complex of soilborne microorganisms rather than a specific individual pathogen $(8,19,29)$ cause replant disease. In apple, it has been customary to assume that replant disease incidence and severity are highest on sites previously occupied by orchards that had been in production for extended periods of time $(9,16)$. However, the fact that similar disease symptoms have been observed in nurseries after a preceding apple planting had occupied the site for 1 or 2 years suggests that a microbial community capable of inducing replant disease may develop rapidly in response to planting apple. The goal of the current study was to examine the composition of soil microbial communities in an orchard possessing adjacent blocks of apple that had been planted in five successive years (first to fifth year of growth) and to correlate observed changes with the ability of the resident microbial community to support apple growth and suppress Rhizoctonia root rot.

\section{MATERIALS AND METHODS}

Study site and soil collection. Studies were conducted in soil obtained from the Wenatchee Valley College Auvil Research and Demonstration (WVC-Auvil) Orchard located $6.4 \mathrm{~km}$ east of East Wenatchee, WA. The site is uniform with respect to soil type (Cowiche silt loam) and had been cropped continuously to wheat monoculture prior to apple orchard establishment in 1992. The orchard blocks studied had been planted during consecutive years (from 1992 to 1996) to 'Fuji' apple on M.26 rootstock and were in the first through fifth years of growth at the time of soil sampling during October and December 1996. For each orchard block, a composite sample was obtained by collecting soil within the root zones of 30 randomly selected trees. Samples were obtained within the tree row 1 to $2 \mathrm{~m}$ from the tree base at a depth of 10 to $30 \mathrm{~cm}$. A 
composite soil sample also was collected from orchard ground located immediately adjacent to the first-year orchard block that had not been cultivated previously to apple (hereafter referred to as noncultivated soil).

Growth of apple in soils from orchard blocks of different ages. Assays were conducted to determine the impact of cropping duration on growth of apple in orchard soils. Apple ('Gala') seeds were surface-sterilized in a $10 \%(\mathrm{vol} / \mathrm{vol})$ solution of commercial bleach (5.25\% sodium hypochlorite) and rinsed for $30 \mathrm{~min}$ under running tap water. Seeds were dusted with captan 50WP and stratified for germination by placing in a plastic bag with moistened paper towels at $4^{\circ} \mathrm{C}$ for a period of 8 weeks. Seeds were sown in plastic flats containing sterile peat moss/perlite growth medium and incubated at $24^{\circ} \mathrm{C}$ with 12 -h photoperiods until seedling emergence. Seedlings were transferred to environmental chambers and grown at $18^{\circ} \mathrm{C}$ with 12-h photoperiods for 6 weeks. Soils from orchard blocks in their first to fifth years of growth and from noncultivated ground were placed in plastic tapered tubes (Ray Leach Cone-tainers, Stuewe \& Sons Inc., Corvallis, OR), and one 6-week-old seedling was planted in each tube. Soil was covered with a 1-cm layer of vermiculite, and $10 \mathrm{ml}$ of water was applied to each tube. Plants were grown for an additional 8 weeks, and plant weights were determined at harvest. Experiments were conducted using a randomized complete block design, with seven seedlings per soil in each of two replicates, and the experiment was repeated once.

The relative impact of the microbial community on growth of apple in noncultivated and third-year orchard soils was assessed. Soils were pasteurized by exposure to steam $\left(97^{\circ} \mathrm{C}\right)$ for $90 \mathrm{~min}$. Gala apple seedlings were planted in pasteurized and natural soils from these orchard blocks. Experiments were conducted under the growth conditions described above. Plants were harvested after 8 weeks, and root weight, shoot weight, and shoot length were determined.

Characterization of soil and rhizosphere microbial communities. Ten Gala seedlings were cultivated in each orchard soil under the conditions described above. Microbial communities associated with the seedlings were characterized in an attempt to describe microbial succession in orchard soils. Soil populations of Pratylenchus spp. were determined by extracting nematodes from four $50-\mathrm{cm}^{3}$ samples for each orchard block, using a pie-pan modification of the Baermann funnel technique. Nematodes were extracted from the complete root system of four apple seedlings grown in soil from each orchard block. Root tissue from individual seedlings was placed in $80 \mathrm{ml}$ of sterile deionized water in 125-ml flasks and incubated on a Gyrotory shaker (model G2; New Brunswick Scientific Co., Edison, NJ) at $200 \mathrm{rpm}$ for $72 \mathrm{~h}$. Nematodes were collected by filtering the soil or root extract twice through a 350-mesh sieve and backwashing into a counting dish. Plantparasitic nematodes were counted with a dissecting microscope and identified to the genus level.

Total soil populations of culturable bacteria, fluorescent pseudomonads, and fungi were estimated for each soil. Six samples were processed for each soil. Suspensions were prepared by adding $0.5 \mathrm{~g}$ of soil to $10 \mathrm{ml}$ of sterile distilled water and vortexing for $60 \mathrm{~s}$. Serial dilutions of the suspension were plated on $1 / 10$-strength tryptic soy agar (TSA; Difco Laboratories, Detroit), King's medium B agar amended with cycloheximide $(100 \mu \mathrm{g} / \mathrm{ml})$, ampicillin $(100 \mu \mathrm{g} / \mathrm{ml})$, and chloramphenicol $(13 \mu \mathrm{g} / \mathrm{ml})\left(\mathrm{KMB}^{+} ; 27\right)$, and $1 / 5$-strength potato dextrose agar (Difco) amended with ampicillin (100 $\mu \mathrm{g} / \mathrm{ml})$ for enumeration of bacteria, fluorescent pseudomonads, and fungi, respectively. Colonies were counted after $72 \mathrm{~h}$ of incubation at $25^{\circ} \mathrm{C}$. For each sample, 10 bacterial isolates were selected randomly from TSA plates and identified by gas chromatography of fatty acid methyl esters (GC-FAME), using a Microbial Identification System equipped with an HP5890 Series II gas chromatograph, HP 3365 Chem Station, and Aerobe library, version 3.9 (Microbial ID Inc., Newark, DE). Preparation and analyses of samples were conducted according to the procedures recommended by the manufacturer.
The relative total composition of the culturable bacteria, fluorescent pseudomonad, and fungal populations colonizing the rhizosphere of apple seedlings grown in soil from each orchard block was determined. Six randomly selected seedlings from each soil were harvested and shaken to remove loosely adhering soil. Root tissue and firmly adhering soil $(0.4 \mathrm{~g})$ were placed in $10 \mathrm{ml}$ of sterile water, vortexed for $60 \mathrm{~s}$, and serial dilutions of the root wash were plated on TSA and $\mathrm{KMB}^{+}$. For each root wash, 10 bacterial colonies were selected randomly from both TSA and $\mathrm{KMB}^{+}$and identified by GCFAME analysis. From the same seedlings, 20 root segments $(0.5$ to $1.0 \mathrm{~cm}$ long) were excised and plated on $1.5 \%$ water agar amended with ampicillin $(100 \mu \mathrm{g} / \mathrm{ml})$. After incubation at room temperature $\left(20\right.$ to $23^{\circ} \mathrm{C}$ ) for $96 \mathrm{~h}$, fungal growth from root segments was examined with a light microscope $(100 \times)$. Fungi were identified to the genus level.

Disease-suppressive potential of resident microflora. Experiments were conducted to determine whether observed changes in the composition of the resident soil microflora with increasing orchard block age resulted in an altered ability to suppress Rhizoctonia root rot of apple. Inoculum of Rhizoctonia solani anastomosis group 5 (AG 5) strain 5-103 was prepared as described previously (18). The pathogen was introduced as colonized oat bran into soil from each of the orchard blocks and noncultivated soil at a concentration of $0.1 \%$ (wt/wt). For each noninfested soil and soil infested with $R$. solani AG 5, 14 Cone-tainers were planted to 4-weekold apple seedlings and grown for 4 weeks in environmental chambers under the growth conditions described above. The ability of the resident microflora to suppress $R$. solani was assessed by comparing the relative growth of apple in infested soil with that obtained in noninfested soil from the same orchard block. To determine whether susceptibility of apple to $R$. solani was affected by plant age, experiments were repeated in noncultivated and third-year orchard soils with 8-week-old seedlings. Seedlings were grown in 16-cmdiameter pots, with five seedlings per pot and four pots per soil. Soils were infested with $R$. solani AG 5 strain 5-103 as described above, seedlings were grown in the greenhouse at $18^{\circ} \mathrm{C}$, and plants were harvested after 10 weeks.

Characterization of antibiotic production by fluorescent Pseudomonas spp. from orchard soils. Experiments were performed to determine whether the relative abilities of soil microbial communities from different WVC-Auvil orchard soils to suppress $R$. solani AG 5 resulted from changes in the frequency of unique traits within bacterial populations. Wheat monoculture selects for a fluorescent pseudomonad population dominated by 2,4-diacetylphloroglucinol (Phl)-producing strains (24). Due to the continuous cropping of the WVC-Auvil site to wheat prior to orchard establishment, the presence of specific antibiotic biosynthetic pathways in the fluorescent pseudomonad population was examined. The frequency of phenazine-1-carboxylic acid (PCA)- and Phl-producing fluorescent pseudomonads in soils and rhizospheres of apple seedlings grown in noncultivated and third-year orchard soils was assessed by a polymerase chain reaction (PCR)-based protocol developed by Raaijmakers et al. (25). Root washes were prepared from six apple transplants grown in soils from WVC-Auvil for 4 weeks as described above, and serial dilutions were plated on $\mathrm{KMB}^{+}$. Six soil suspensions for each orchard sample were prepared as described above, and serial dilutions were plated on $\mathrm{KMB}^{+}$. Ten fluorescent pseudomonad isolates were selected randomly from each seedling root wash or soil suspension. A cell lysis assay was conducted as described by Raaijmakers et al. (25), and the number of fluorescent pseudomonads possessing genes for Phl and PCA biosynthesis was determined by PCR analysis with the primers and reaction conditions used by Raaijmakers et al. (25). Primers used were synthesized by Operon Technologies Inc. (Alameda, CA).

Effect of plant growth cycles on microbial communities in the apple rhizosphere. Soil was collected from the noncultivated area within the WVC-Auvil orchard during March 1997. Ninetyeight individual Cone-tainers were filled with $100 \mathrm{~g}$ of soil and 
planted to 6-week-old 'Gala' apple seedlings. Plants were grown in environmental growth chambers as described above, and 14 randomly selected seedlings were harvested after 4 weeks. For the remaining plants, shoots were excised at the soil surface, and the soil and associated root systems from individual Cone-tainers were decanted into a plastic bag and shaken to aerate and mix the soil and dispensed back into the same tube. Soil was incubated in environmental growth chambers for $48 \mathrm{~h}$ and replanted with 6-weekold seedlings. After the initial planting cycle, $15 \mathrm{ml}$ of Hoaglund's

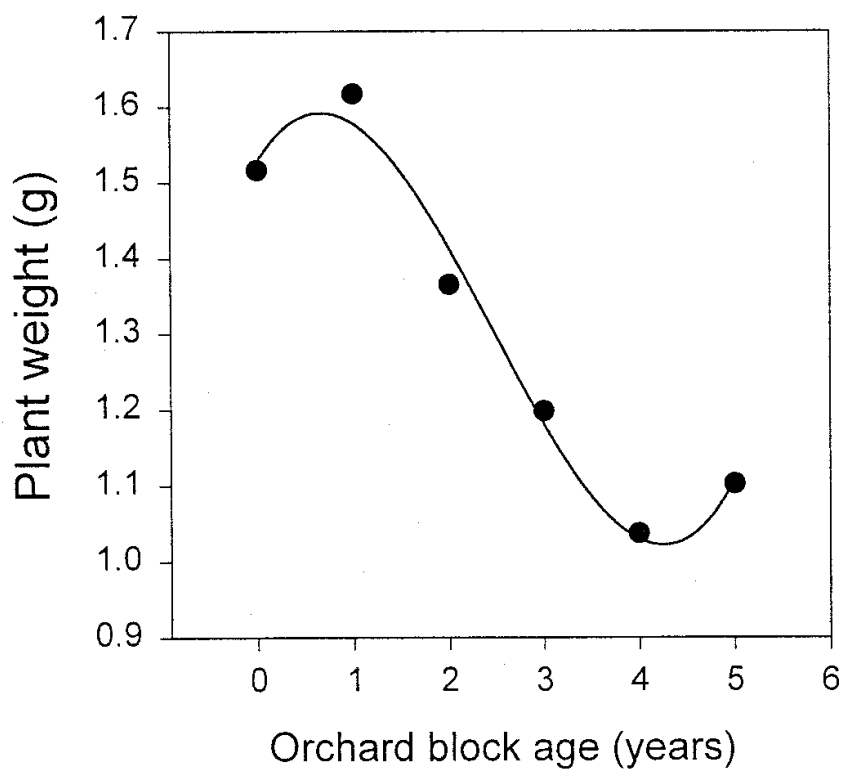

Fig. 1. Relationship between the age of an apple block at the Wenatchee Valley College Auvil Research and Demonstration Orchard, WA, from which soil was collected and the biomass of 'Gala' apple seedlings. Seedlings were 6-weeksold at planting and were grown for an additional 8 weeks at $18^{\circ} \mathrm{C}$ with 12 -h photoperiods. Each data point is the mean of two replicates derived from seven plants each. Polynomial regression $\left(y=1.53+0.207 x-0.181 x^{2}+0.0246 x^{3}, R^{2}=\right.$ 0.98 ) best described the relationship.

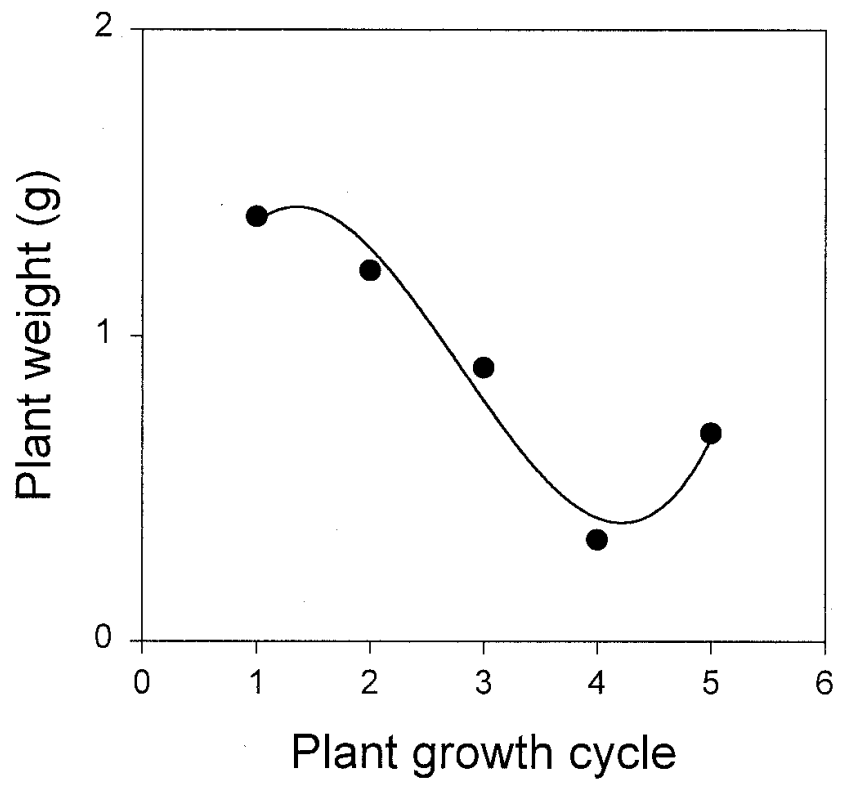

Fig. 2. Effect of repeated growth cycles in previously noncultivated soil from the Wenatchee Valley College Auvil Research and Demonstration Orchard, WA, on biomass of 'Gala' apple seedlings. Seedlings were 6 weeks old at planting and were grown for an additional 4 weeks at $18^{\circ} \mathrm{C}$ with 12 -h photoperiods. Each data point is the mean derived from 14 plants. Polynomial regression $\left(y=0.516+1.5 x-0.733 x^{2}+0.0877 x^{3}, R^{2}=0.97\right)$ best described the relationship between plant cycle and seedling biomass. solution was applied to each Cone-tainer at planting. The process of plant growth and harvesting was repeated for five cycles.

At harvest, plants were removed from the plastic tubes and shaken vigorously to remove loosely adhering soil. The root systems from eight seedlings were washed, and root and shoot weights were determined. Six of the eight seedlings were used to characterize the fungal communities colonizing the roots of apple, with 20 root segments from each plant plated on $1.5 \%$ water agar, and fungi were identified as described above. Shoots from the remaining six seedlings for which roots were not washed were excised and weighed, and roots were used for analysis of total culturable bacterial communities colonizing the rhizosphere of apple. Roots were processed, bacteria were isolated, and bacterial identifications were conducted by GC-FAME analysis as described above.

Statistical analysis. The relationships between the age of the orchard block from which soil was collected or plant growth cycle and biomass of apple seedlings grown in the respective soils were determined by polynomial regression. A contingency table chi-square test of the raw data was used to detect significant changes in soil and rhizosphere microbial community composition with increasing orchard block age. Microbial population and plant growth data were subjected to analysis of variance, and means were separated by the Student-Newman-Keuls test. Statistical analyses were performed using SigmaStat, version 2.0 (SPSS, San Rafael, CA) or general linear models procedures (SAS Institute, Cary, NC).

\section{RESULTS}

Impact of previous cropping duration on growth of 'Gala' apple seedlings in orchard soils. Growth of apple transplants in soil from the WVC-Auvil orchard varied with the age of the orchard block from which soil was obtained. Biomass of apple seedlings grown in noncultivated and first-year orchard block soils was similar. Thereafter, plant biomass exhibited a general decline relative to that achieved in noncultivated orchard soil as the period for which soils were cropped to apple increased (Fig. 1). The fact that the decline in plant growth could be attributed to changes in the resident soil microbiota was evidenced by the impact of soil pasteurization on plant growth in noncultivated soil and soil from the third-year orchard block. Soil pasteurization had no significant $(P=$ 0.05 ) effect on biomass or height of seedlings grown in noncultivated orchard soil. Plants averaged 1.80 and $1.86 \mathrm{~g}$ in weight and 20.7 and $20.0 \mathrm{~cm}$ in shoot length in noncultivated-natural and noncultivated-pasteurized soils, respectively. In contrast, pasteurization of third-year orchard soil resulted in significant $(P<0.0001)$ increases in both biomass and height of seedlings. Average plant weight of apple seedlings grown in third-year orchard soil increased from 1.24 to $1.91 \mathrm{~g}$, and average shoot length increased from 14.7 to

TABLE 1. Effect of Rhizoctonia solani anastomosis group 5 strain (AG 5) strain 5-103 on growth of 'Gala' apple seedlings in soil collected from the firstthrough fifth-year blocks and noncultivated soil from the Wenatchee Valley College Auvil Research and Demonstration Orchard, WA

\begin{tabular}{lccc}
\hline & \multicolumn{2}{c}{ Plant weight $(\mathrm{g})^{\mathrm{x}}$} & \\
\cline { 2 - 3 } Orchard block & Control & + R. solani $^{\mathrm{z}}$ & $+\mathrm{R}: \mathrm{C}^{\mathrm{y}}$ \\
\hline Noncultivated & $0.88 \mathrm{a}$ & $0.89 \mathrm{a}$ & 1.02 \\
First-year & $0.83 \mathrm{a}$ & $0.77 \mathrm{a}$ & 0.91 \\
Second-year & $0.82 \mathrm{a}$ & $0.81 \mathrm{a}$ & 0.99 \\
Third-year & $0.66 \mathrm{a}$ & $0.36 \mathrm{~b}$ & 0.55 \\
Fourth-year & $0.67 \mathrm{a}$ & $0.47 \mathrm{~b}$ & 0.70 \\
Fifth-year & $0.58 \mathrm{a}$ & $0.37 \mathrm{~b}$ & 0.64 \\
\hline
\end{tabular}

${ }^{x}$ Means in the same row followed by the same letter are not significantly different $(P=0.05)$ based on the Student-Newman-Keuls procedure.

y Ratio of weight of seedlings grown in soil infested with $R$. solani AG 5 strain 5-103 versus weight of seedlings grown in the same soil without the introduced pathogen.

${ }^{\mathrm{z}}+R$. solani. Fungal inoculum was prepared and introduced into soil, and plants were grown for 4 weeks in controlled environment chambers as described in text. 
$21.2 \mathrm{~cm}$ in response to soil pasteurization. Growth of apple in pasteurized third-year orchard soil was equivalent to that obtained in noncultivated-natural orchard soil. Soil pasteurization had no apparent impact on plant nutrition; tissue analysis (Soiltest Farm Consultants Inc., Moses Lake, WA) detected no difference in total N, P, K, or $\mathrm{S}$ in leaves of apple seedlings grown in natural or pasteurized WVC-Auvil orchard soils.

Similar results were obtained in response to the short-term cycling of apple in previously noncultivated soil from the WVC-Auvil orchard. A consistent decline in seedling biomass was observed during successive cycles of plant growth (Fig. 2), with mortality of apple transplants observed in planting cycles 4 and 5 .

Effect of cropping duration on Rhizoctonia-suppressive potential of soil microflora. The ability of an introduced isolate of $R$. solani AG 5 to suppress growth of apple in WVC-Auvil orchard soil varied with the age of the block from which soil was collected. Growth of 4-week-old apple transplants in soil collected from the first- or second-year orchard blocks and infested with $R$. solani AG 5 strain 5-103 was not different from that obtained in corresponding noninfested soils (Table 1). However, biomass of apple seedlings grown in soil collected from the third-, fourth-, or fifth-year blocks and infested with $R$. solani was reduced relative to that obtained in corresponding noninfested soils.

Similar results were obtained for 8-week-old apple transplants. A significant interaction between orchard block soil and $R$. solani AG 5 on growth of apple was observed (Table 2). $R$. solani caused a reduction in root and shoot biomass of seedlings grown in thirdyear orchard soil but not in seedlings grown in noncultivated soil (Table 3). Seedling mortality was not observed in noncultivated soil infested with $R$. solani, but $70 \%$ of seedlings grown in thirdyear orchard soil infested with the pathogen were dead at harvest.

Effect of cropping duration on composition of soil microbial communities. Populations of plant-parasitic nematodes were low in all soil samples from the WVC-Auvil orchard regardless of cropping history. Many genera commonly associated with apple, including Paratylenchus and Xiphinema, were not detected in soils or roots from the site. Populations of the lesion nematode, Pratylenchus spp., ranged from 4 to $11 / 100 \mathrm{~cm}^{3}$ of soil in all orchard blocks. Populations of Pratylenchus spp. ranged from 17/g of root for apple seedlings grown in noncultivated soil to $41 / \mathrm{g}$ of root for seedlings grown in fourth-year orchard soil.

Soil populations of culturable bacteria increased significantly $(P<0.0001)$ from $1.9 \times 10^{6} \mathrm{CFU} / \mathrm{g}$ in noncultivated soil to $1.7 \times$ $10^{7} \mathrm{CFU} / \mathrm{g}$ in second-year orchard soil in response to planting apple. Bacterial populations in soils from the second- through fifth-year orchard blocks were similar. A significant shift in composition of bacterial populations was observed between first- and second-year $(P<0.0001)$, second- and third-year $(P=0.0085)$, and third- and fourth-year orchard block soils $(P<0.0001)$. Bacillus megaterium clearly dominated the bacterial community isolated from noncultivated soil and soil collected from the first-year block (Table 4). The population of Bacillus megaterium declined with increasing orchard block age and represented $<5 \%$ of the culturable bacteria population isolated from fifth-year orchard block soil. In contrast, the relative population of Pseudomonas fluorescens increased with increasing orchard block age. Pseudomonas fluorescens was not rep-

TABLE 2. Effects of soil source, Rhizoctonia solani anastomosis group 5 strain 5-103, and their interactions on the growth of 8-week-old 'Gala' apple seedlings in noncultivated and third-year block soils from Wenatchee Valley College Auvil Research and Demonstration Orchard, WA ${ }^{z}$

\begin{tabular}{lrrrrrrrr}
\hline & \multicolumn{2}{c}{ Shoot length } & & \multicolumn{2}{c}{ Shoot weight } & & \multicolumn{2}{c}{ Root weight } \\
\cline { 2 - 3 } Source & \multicolumn{1}{c}{$F$} & $P>F$ & & $F$ & $P>F$ & & \multicolumn{1}{c}{$F$} & $P>F$ \\
\hline Soil (S) & 94.74 & 0.0001 & & 71.68 & 0.0001 & 83.67 & 0.0001 \\
R. solani (R) & 1.42 & 0.2377 & & 2.89 & 0.0950 & & 2.01 & 0.1617 \\
S-R & 2.40 & 0.1268 & & 3.76 & 0.0577 & & 14.77 & 0.0003 \\
\hline
\end{tabular}

${ }^{\mathrm{z}}$ Degree of freedom $=1$ for all values; residual $=76$ for all values. resented in the total population of culturable bacteria from noncultivated soil but comprised $75 \%$ of the population isolated from fifthyear orchard block soil.

Populations of culturable bacteria recovered from the rhizosphere of apple seedlings grown in soil from the WVC-Auvil orchard were comparable in size among orchard blocks of different ages, ranging from $1.8 \times 10^{8} \mathrm{CFU} / \mathrm{cm}$ of root in second-year orchard soil to $3.8 \times 10^{8} \mathrm{CFU} / \mathrm{cm}$ of root in third-year orchard soil. However, qualitative attributes of bacterial populations varied significantly $(P<$ 0.02 ) among each of the soils. Burkholderia cepacia dominated the bacterial community isolated from the rhizosphere of apple grown in previously noncultivated orchard soil (Table 5). The relative population of Burkholderia cepacia recovered from roots of apple seedlings declined precipitously with increasing age of the orchard block from which soil was collected. Several bacterial genera, including Agrobacterium, Flavobacterium, Pseudomonas, and Variovorax represented minor components of the rhizosphere population from apple grown in noncultivated soil but were significant elements of the population isolated from the rhizosphere of seedlings grown in soil that had been planted to apple for three or more years.

Soil populations of fluorescent pseudomonads ranged from $6.1 \times$ $10^{4} \mathrm{CFU} / \mathrm{g}$ in noncultivated soil to $1.4 \times 10^{6} \mathrm{CFU} / \mathrm{g}$ in fifth-year orchard soil. Although total soil populations of fluorescent pseudomonads differed significantly $(P<0.0001)$ between noncultivated and cultivated orchard soils, total populations recovered from the rhizosphere of seedlings grown in the soils did not. Rhizosphere

TABLE 3. Effect of Rhizoctonia solani anastomosis group 5 strain 5-103 on growth of 'Gala' apple seedlings in noncultivated and third-year soils from Wenatchee Valley College Auvil Research and Demonstration Orchard, WA

\begin{tabular}{|c|c|c|c|}
\hline Soil & $\begin{array}{l}\text { Shoot length } \\
(\mathrm{cm})\end{array}$ & $\begin{array}{c}\text { Shoot weight } \\
(\mathrm{g})\end{array}$ & $\begin{array}{c}\text { Root weight } \\
\text { (g) }\end{array}$ \\
\hline Noncultivated & 9.3 & 1.01 & 0.78 \\
\hline Noncultivated $+R$. solan $i$ & 9.6 & 1.03 & 0.83 \\
\hline Third-year & 6.3 & 0.48 & 0.41 \\
\hline Third-year $+R$. solani ${ }^{\mathrm{z}}$ & 5.1 & 0.24 & 0.11 \\
\hline
\end{tabular}

y Fungal inoculum was prepared and introduced into soil as described in text. Soils were planted to 8-week-old 'Gala' apple seedlings, and seedlings were grown for an additional 10 weeks in the greenhouse at $18^{\circ} \mathrm{C}$.

${ }^{\mathrm{z}}$ Mortality was $70 \%$ (mortality for other soils was $0 \%$ ).

TABLE 4. Identity of bacteria isolated from soils cultivated to apple for 0 to 5 years at the Wenatchee Valley College Auvil Research and Demonstration Orchard, WA

\begin{tabular}{|c|c|c|c|c|c|c|}
\hline \multirow[b]{2}{*}{ Species } & \multicolumn{6}{|c|}{ Orchard block age (years) ${ }^{\mathrm{y}}$} \\
\hline & $\mathrm{NC}^{\mathrm{z}}$ & 1 & 2 & 3 & 4 & 5 \\
\hline Bacillus atrophaeus & & 6.7 & 1.7 & & & \\
\hline Bacillus brevis & 1.7 & & & 1.7 & & \\
\hline Bacillus chitinosporus & & 5.0 & & & 1.7 & \\
\hline Bacillus circulans & 5.0 & & & & & \\
\hline Bacillus laterosporus & & & & 1.7 & & \\
\hline Bacillus megaterium & 81.7 & 70.0 & 35.0 & 55.0 & 11.7 & 3.3 \\
\hline Bacillus mycoides & & 1.7 & & & & \\
\hline Bacillus pumilus & & 3.3 & & & & \\
\hline Bacillus sphaericus & & & & 1.7 & & \\
\hline Bacillus thuringiensis & & & & 3.3 & & \\
\hline Comamonas acidivorans & & & 1.7 & & 3.3 & 1.7 \\
\hline Micrococcus luteus & 1.7 & & & & & \\
\hline Paenibacillus pabuli & 3.3 & & & 3.3 & 1.7 & \\
\hline Pseudomonas aureofaciens & & & 3.3 & & 3.3 & \\
\hline Pseudomonas fluorescens & & 3.3 & 30.0 & 18.3 & 58.3 & 75.0 \\
\hline Pseudomonas putida & & 3.3 & 20.0 & 3.3 & 3.3 & 3.3 \\
\hline Pseudomonas syringae & & & 1.7 & 3.3 & 6.7 & 11.7 \\
\hline Serratia grimesii & & 1.7 & & & & \\
\hline Sporosarcina ureae & 3.3 & & & & & \\
\hline Unknown & 3.3 & 6.7 & 6.7 & 8.3 & 10.0 & 5.0 \\
\hline
\end{tabular}


populations ranged from $1.1 \times 10^{4} \mathrm{CFU} / \mathrm{cm}$ of root in noncultivated soil to $4.6 \times 10^{4} \mathrm{CFU} / \mathrm{cm}$ of root in third-year orchard soil. The composition of the fluorescent pseudomonad population colonizing the rhizosphere of apple seedlings grown in soil from the WVC-Auvil orchard varied with orchard block age (Table 6). Significant shifts in the composition of the community were detected between noncultivated and first-year $(P=0.003)$ and first- and second-year $(P=0.0012)$ orchard block soils. In noncultivated soil, Pseudomonas putida dominated the fluorescent pseudomonad population recovered from the rhizosphere of apple seedlings. The relative proportion of Pseudomonas putida in the rhizosphere population of fluorescent pseudomonads decreased with increasing age of the orchard block from which soil was collected and was associated with a concomitant increase in the relative population of Pseudomonas fluorescens btp C.

Pseudomonas putida and Pseudomonas fluorescens btp C dominated the fluorescent pseudomonad populations recovered from the rhizospheres of apple seedlings grown in noncultivated and thirdyear orchard soils, respectively. Therefore, studies were conducted to assess the ability of these two bacterial populations to suppress

TABLE 5. Identity of bacteria isolated from the rhizosphere of 'Gala' apple seedlings grown in soil cultivated to apple for 0 to 5 years at the Wenatchee Valley College Auvil Research and Demonstration Orchard, WA

\begin{tabular}{|c|c|c|c|c|c|c|}
\hline \multirow[b]{2}{*}{ Genus } & \multicolumn{6}{|c|}{ Orchard block age (years) } \\
\hline & $\mathrm{NC}^{\mathrm{z}}$ & 1 & 2 & 3 & 4 & 5 \\
\hline Acidovarax & & & & & 1.7 & \\
\hline Agrobacterium & & 5.0 & 3.3 & 6.7 & 6.7 & 16.7 \\
\hline Arthrobacter & & 5.0 & 1.7 & & & 1.7 \\
\hline Bacillus & & 3.3 & 1.7 & 3.3 & 1.7 & \\
\hline Burkholderia & 86.7 & 41.7 & 21.7 & 16.7 & & 8.3 \\
\hline Cellulomonas & & 1.7 & & & & \\
\hline Comamonas & & & & 1.7 & 3.3 & \\
\hline Cytophaga & & 1.7 & 5.0 & & & 3.3 \\
\hline Enterococcus & & & & & 1.7 & 1.7 \\
\hline Flavobacterium & 1.7 & 3.3 & 8.3 & 26.7 & 10.0 & 5.0 \\
\hline Janthinobacterium & & & 3.3 & & & \\
\hline Micrococcus & 1.7 & & & & 1.7 & \\
\hline Phyllobacterium & & 1.7 & 5.0 & 1.7 & 3.3 & 5.0 \\
\hline Pseudomonas & 3.3 & 11.7 & 23.3 & 13.3 & 18.3 & 31.7 \\
\hline Rhodococcus & & 1.7 & 3.3 & 1.7 & 1.7 & 1.7 \\
\hline Sphingobacterium & & & 5.0 & 1.7 & 1.7 & \\
\hline Sphingomonas & & & & 1.7 & & \\
\hline Stenotrophomonas & & 1.7 & 10.0 & & 1.7 & 6.7 \\
\hline Variovorax & 3.3 & 11.7 & & 21.7 & 38.3 & 11.7 \\
\hline Xanthobacter & & & 3.3 & & & \\
\hline Unknown & 3.3 & 10.0 & 8.3 & 3.3 & 8.3 & 6.7 \\
\hline
\end{tabular}

${ }^{y}$ Values are a percentage of the total number of bacterial isolates examined for a given soil.

${ }^{\mathrm{z}}$ Noncultivated orchard soil.

TABLE 6. Composition of the fluorescent pseudomonad population isolated from the rhizosphere of 'Gala' apple seedlings grown in soil cultivated to apple for 0 to 5 years at the Wenatchee Valley College Auvil Research and Demonstration Orchard, WA

\begin{tabular}{lrrrrrc}
\hline \multirow{2}{*}{$\begin{array}{l}\text { Pseudomonas } \\
\text { species }\end{array}$} & \multicolumn{6}{c}{ Orchard block age (years) } \\
\cline { 2 - 7 } & $\mathrm{NC}^{\mathrm{z}}$ & \multicolumn{1}{c}{1} & \multicolumn{1}{c}{2} & \multicolumn{1}{c}{3} & \multicolumn{1}{c}{4} & \multicolumn{1}{c}{5} \\
\hline P. aureofaciens & 1.7 & 3.3 & 5.0 & 3.3 & 5.0 & 1.7 \\
P. fluorescens btp B & 3.3 & & & & & \\
$P$. fluorescens btp C & 6.7 & 33.3 & 68.3 & 68.3 & 61.7 & 85.0 \\
$P$. fluorescens btp F & 6.7 & 3.3 & & & & \\
P. fluorescens btp G & & & & 3.3 & & \\
P. marginalis & 11.7 & 1.7 & & & & \\
$P$. putida btp A & 11.7 & 33.3 & 5.0 & & & 13.3 \\
P. putida btp B & 53.3 & 13.3 & 11.7 & 11.7 & & \\
P. syringae & 3.3 & 10 & 10 & 11.7 & 33.3 & \\
Unknown & 1.7 & 1.7 & & 1.7 & & \\
\hline
\end{tabular}

${ }^{y}$ Values are a percentage of the total number of fluorescent pseudomonad isolates examined for a given soil.

${ }^{\mathrm{z}}$ Noncultivated orchard soil. in vitro growth of $R$. solani AG 5 strain 5-103. Fungal growth-inhibition assays were conducted with 15 isolates each of Pseudomonas putida and Pseudomonas fluorescens btp C randomly selected from the collection of fluorescent pseudomonads recovered from noncultivated and third-year orchard soils. Assays were conducted on nutrient broth yeast-extract agar (30) as described previously (21). After $96 \mathrm{~h}$ of incubation at $22^{\circ} \mathrm{C}$, the width of inhibition zones between the margin of bacterial colonies and $R$. solani AG 5 strain 5-103 averaged 0.9 and $4.8 \mathrm{~mm}$ for isolates of Pseudomonas fluorescens btp C and Pseudomonas putida, respectively. The majority of isolates of Pseudomonas fluorescens btp C (11 of $15)$ failed to suppress in vitro growth of $R$. solani.

Phenazine biosynthetic loci were not detected among apple rhizosphere isolates and were detected among only 3.3\% of soil isolates of fluorescent Pseudomonas spp. examined by the PCR-based protocol of Raaijmakers et al. (25). In contrast, 35 and $6.7 \%$ of fluorescent pseudomonads recovered from noncultivated and thirdyear orchard soils, respectively, possessed the Phl biosynthetic loci. Phl-producing fluorescent pseudomonads comprised 3.3\% of the rhizosphere population from apple seedlings grown in noncultivated soil but were not detected in the population from seedlings grown in third-year orchard soil.

No discernible trend in total size of fungal populations from different orchard soils were apparent based on the culture-based procedures used. Fungal populations averaged $\approx 10^{6} / \mathrm{g}$ in each soil. The fungal community recovered from apple seedling roots varied with orchard block age, with significant shifts in composition detected between the community recovered from seedlings grown in third- and fourth-year orchard blocks $(P=0.0005)$. The fungal population from seedlings cultivated in soil from younger orchard blocks or noncultivated soil was dominated by genera typically considered saprophytes, including Aspergillus, Mucor, Paecilomyces, Trichoderma, and Ulocladium (Table 7). In general, with the exception of Trichoderma and Mucor, the relative isolation frequency for these fungal genera from apple seedling roots declined with increasing age of the orchard block from which soil was collected. In contrast, isolates of Rhizoctonia spp. were not recovered from apple seedlings grown in noncultivated or first-year orchard soils but became increasingly prevalent as orchard age increased. Rhizoctonia spp. were first isolated from seedlings grown in soil from the second-year block and represented $37 \%$ of the fungal isolates recovered from the roots of apple grown in soil from the fifth-year block. Isolates of Pythium spp. and Phytophthora cactorum were recovered only from seedlings grown in soil from the fourth- or fifth-year orchard blocks.

TABLE 7. Composition of the fungal community recovered from the roots of 'Gala' apple seedlings grown in soils from the Wenatchee Valley College Auvil Research and Demonstration Orchard, WA

\begin{tabular}{|c|c|c|c|c|c|c|}
\hline \multirow[b]{2}{*}{ Genus } & \multicolumn{6}{|c|}{ Orchard block age (years) } \\
\hline & $\mathrm{NC}^{\mathrm{z}}$ & 1 & 2 & 3 & 4 & 5 \\
\hline Alternaria & 2.7 & 1.7 & 8.6 & 1.6 & & \\
\hline Aspergillus & 8.2 & & & & 2.7 & \\
\hline Cylindrocarpon & & 1.7 & 2.9 & & 5.4 & 2.2 \\
\hline Fusarium & 5.5 & 13.6 & 5.7 & 34.4 & 2.7 & 2.2 \\
\hline Mortierella & & & 8.6 & & & \\
\hline Мисоr & 16.2 & 24.6 & 22.8 & 11.4 & 16.2 & 17.4 \\
\hline Paecilomyces & 26.0 & 18.6 & 25.7 & 13.1 & 16.2 & 6.5 \\
\hline Penicillium & 2.7 & & & & & \\
\hline Phialophora & 1.4 & & & & 5.4 & \\
\hline Phytophthora & & & & & 8.1 & 4.3 \\
\hline Pythium & & & & & 8.1 & 6.5 \\
\hline Rhizoctonia & & & 11.4 & 13.1 & 18.9 & 37.0 \\
\hline Trichoderma & 19.4 & 32.9 & 14.3 & 21.3 & 13.5 & 23.9 \\
\hline Ulocladium & 17.8 & 5.1 & & 4.9 & 2.7 & \\
\hline No. of isolates & 73 & 59 & 70 & 61 & 74 & 92 \\
\hline
\end{tabular}

$\mathrm{y}$ Values are a percentage of the total number of fungal isolates recovered from apple seedlings grown in a given soil.

${ }^{\mathrm{z}}$ Noncultivated orchard soil. 
Effect of apple seedling cycling on composition of rhizosphere fungal and bacterial communities. Composition of the rhizosphere bacterial community varied with seedling growth cycle; a significant $(P=0.0001)$ shift was detected between growth cycles three and four. After one growth cycle, Burkholderia cepacia was the dominant bacterial species recovered from the apple rhizosphere (Table 8). Burkholderia cepacia represented between one-quarter and one-third of the total culturable bacteria population recovered from the apple rhizosphere during each of the first three growth cycles but represented $<5 \%$ of the total population recovered from seedlings after cycles four and five. Bacteria belonging to the genera Arthrobacter, Bacillus, Cytophaga, and Hydrogenophaga were present in relatively consistent proportions of the total population recovered from the rhizosphere of apple during the course of the five growth cycles. Pseudomonas spp. dominated the bacterial community recovered from the rhizosphere of apple seedlings grown during the fifth cycle.

The fungal population recovered from the roots of apple varied among growth cycles; a significant $(P=0.0001)$ shift in composition was observed between cycles three and four. During the initial planting cycle, the fungal community was dominated by genera typically characterized as saprophytes. Trichoderma spp. represented the vast majority of isolates, but the relative proportion of Trichoderma in the total fungal population recovered from apple roots declined over the series of planting cycles (Table 9). Repeated cycling of soil to apple seedlings resulted in an increase in the frequency of isolation for several fungal genera, including Phytophthora, Pythium, Rhizoctonia, and Trichothecium, from apple seedling roots.

\section{DISCUSSION}

Growth of apple on replant sites typically is retarded relative to growth observed in soils that have not been cropped previously to apple. The diminished growth of apple can be observed readily, even when comparing the growth of trees in replant and nonreplant soils

TABLE 8. Identity of bacteria isolated from the rhizosphere of 'Gala' apple seedlings grown for five consecutive cycles in previously noncultivated soil from the Wenatchee Valley College Auvil Research and Demonstration Orchard, WA

\begin{tabular}{|c|c|c|c|c|c|}
\hline \multirow[b]{2}{*}{ Genus } & \multicolumn{5}{|c|}{ Growth cycle ${ }^{\mathrm{z}}$} \\
\hline & 1 & 2 & 3 & 4 & 5 \\
\hline Acidovorax & 1.7 & 1.7 & 1.7 & & 5.0 \\
\hline Agrobacterium & & 1.7 & & 3.3 & 6.7 \\
\hline Arthrobacter & 10.0 & 10.0 & 8.3 & 6.7 & 8.3 \\
\hline Bacillus & 16.7 & 5.0 & 5.0 & 23.3 & 16.7 \\
\hline Brevibacterium & & & 1.7 & & \\
\hline Burkholderia & 26.7 & 28.3 & 33.3 & 1.7 & 3.3 \\
\hline Cellulomonas & & & & 1.7 & \\
\hline Chryseobacterium & & & & 1.7 & \\
\hline Cytophaga & 1.7 & 1.7 & 5.0 & 5.0 & 5.0 \\
\hline Enterobacter & & 1.7 & & & \\
\hline Enterococcus & & 3.3 & 6.7 & & \\
\hline Flavobacterium & & & & 1.7 & 1.7 \\
\hline Hydrogenophaga & 5.0 & 5.0 & 1.7 & 5.0 & 1.7 \\
\hline Janthinobacterium & & & 1.7 & 1.7 & \\
\hline Kluyvera & & & & & 1.7 \\
\hline Micrococcus & & & & 8.3 & 1.7 \\
\hline Paenibacillus & 3.3 & 1.7 & & & \\
\hline Pantoea & & 1.7 & 3.3 & & \\
\hline Paracoccus & & 1.7 & 3.3 & & \\
\hline Phyllobacterium & 1.7 & 5.0 & 3.3 & 1.7 & \\
\hline Pseudomonas & 15.0 & 11.7 & 8.3 & 31.7 & 43.3 \\
\hline Rhodococcus & 6.7 & 3.3 & & & \\
\hline Sphingomonas & & 1.7 & & & \\
\hline Variovorax & 1.7 & 13.3 & 8.3 & & \\
\hline Xanthobacter & 1.7 & & 3.3 & & \\
\hline Xanthomonas & 3.3 & 1.7 & 1.7 & & \\
\hline Unknown & 5.0 & & 3.3 & 6.7 & 5.0 \\
\hline
\end{tabular}

$\mathrm{z}$ Values are a percentage of the total number of bacterial isolates examined for a given soil. separated only by the width of an orchard aisle on the same site. This phenomenon, termed replant disease, has been attributed to a variety of biotic and abiotic causal factors. Although abiotic factors can contribute to disease expression, the current and other studies $(1,4,8,19,26,28)$ clearly point to the primary role of biotic factors in disease development.

As commonly occurs when annual crops are grown in continuous monoculture, specific changes in soil microbial communities were observed in the perennial apple crop system studied here with increasing duration of crop production. As orchard block age increased, the resident soil microflora was transformed from one that supported optimal apple growth to one that induced symptoms of replant disease in apple seedlings cultivated in orchard soils, including reductions in plant biomass and shoot elongation. Pasteurization of soil had no impact on growth of apple seedlings in noncultivated orchard soil but significantly enhanced the height and weight of seedlings grown in third-year orchard soil. Enhanced seedling growth in pasteurized soil was not associated with altered plant nutrition. In addition, growth of apple in pasteurized replant soil was equal to that achieved in noncultivated soil. These findings demonstrate that the reduction in plant growth observed in orchard soils in response to increased cropping duration resulted directly from changes in the soil microbial community. Remarkably, similar changes in the composition of both fungal and bacterial populations, and associated reductions in growth of apple seedlings, were induced by cropping noncultivated orchard soil to five successive growth and harvest cycles of 'Gala' apple seedlings, indicating that the transformation of soil microbial populations was induced by the plant. In addition, the findings suggest that the reduction in apple seedling growth observed in orchard soils in response to increased cropping duration resulted directly from changes in the composition of the soil microbial community, rather than from abiotic elements in the soil environment.

Diminished growth of apple in orchard soils with increasing orchard block age was not associated with any significant change in soil or root populations of plant-parasitic nematodes, including Pratylenchus spp. Populations of Pratylenchus spp. were below reported damage threshold populations (25 to $150 / 100 \mathrm{~cm}^{3}$ of soil) in all orchard soils (9), and populations did not exceed 41/g of root for seedlings grown in these soils. In a previous study, control of plant-parasitic nematodes did not significantly enhance the growth of apple in replant soils when seedlings were infested with Pratylenchus spp. at populations as high as 134/g of root (19). Thus, the low root populations of Pratylenchus spp. documented in the cur-

TABLE 9. Composition of the fungal community recovered from roots of 'Gala' apple seedlings grown for five consecutive cycles in noncultivated soil from Wenatchee Valley College Auvil Research and Demonstration Orchard, WA

\begin{tabular}{|c|c|c|c|c|c|}
\hline \multirow[b]{2}{*}{ Genus } & \multicolumn{5}{|c|}{ Growth cycle ${ }^{z}$} \\
\hline & 1 & 2 & 3 & 4 & 5 \\
\hline Acremonium & 1.8 & 1.4 & 5.6 & & \\
\hline Alternaria & 1.8 & 1.4 & & 0.9 & 0.8 \\
\hline Aspergillus & & 12.8 & 1.4 & 2.6 & 1.5 \\
\hline Cylindrocarpon & 5.7 & 4.3 & 7.0 & 6.1 & 12.8 \\
\hline Fusarium & 13.2 & 10.0 & 8.5 & 14.9 & 8.3 \\
\hline Mortierella & & 2.8 & & 0.9 & \\
\hline Mucor & 1.8 & 1.4 & & & 0.8 \\
\hline Paecilomyces & 13.2 & 8.6 & 36.6 & 11.4 & 8.3 \\
\hline Penicillium & 11.3 & 17.1 & 7.0 & 3.5 & 7.5 \\
\hline Phialophora & & 4.3 & 4.2 & 1.8 & \\
\hline Phytophthora & & & & 14.9 & 12.8 \\
\hline Pythium & & 1.4 & 2.8 & 6.1 & 9.8 \\
\hline Rhizoctonia & & 4.3 & 5.6 & 6.1 & 10.5 \\
\hline Trichoderma & 43.4 & 35.7 & 21.1 & 9.6 & 14.3 \\
\hline Trichothecium & & & 1.4 & 11.4 & 9.8 \\
\hline Ulocladium & 7.5 & 4.3 & 4.2 & 8.8 & 2.3 \\
\hline No. of isolates & 113 & 70 & 71 & 114 & 132 \\
\hline
\end{tabular}

${ }^{z}$ Values are a percentage of the total number of fungal isolates recovered from apple seedlings grown in a given soil. 
rent study suggest that the lesion nematode did not contribute to the reductions in seedling growth observed in response to increased duration of apple cultivation in WVC-Auvil orchard soils.

Reductions in apple seedling growth observed in soils from orchard blocks that had been established for three or more years, relative to growth obtained in noncultivated soil, were associated with changes in the fungal community colonizing apple roots. In particular, reduced plant growth was associated with increased frequency in the recovery of plant-pathogenic fungi, including species of Rhizoctonia, Pythium, and Phytophthora. The same response in both plant growth and alteration of the fungal community colonizing apple roots was achieved in previously noncultivated orchard soil by planting the soils to successive cycles of apple. Although the current study involved only a single orchard, the results provide additional support for the conclusion that replant disease of apple in Washington is caused primarily by a fungal complex (19).

It has been suggested that apple replant disease is limited primarily to sites previously occupied by very old trees $(9,16)$. Data from the current study suggest that populations of soilborne fungi that play a role in the development of apple replant disease increase rapidly in response to planting soils to apple. A pathogen complex capable of inducing replant disease symptoms was present within two years (third growth year) of orchard establishment at the WVCAuvil orchard. In addition, the pathogen complex contained the key fungal elements previously shown to be the dominant cause of apple replant disease in Washington (19). Thus, it is likely that apple replant disease will not be confined to very old orchard sites but has the potential to be a problem even in short-term plantings of apple, such as those typically associated with the production of orchard planting stock in nursery management systems.

Soil from noncultivated portions of the WVC-Auvil orchard was suppressive toward the development of Rhizoctonia root rot of apple caused by an introduced strain of $R$. solani AG 5. However, soils that had been planted to apple for 2 years or longer were conducive to the development of Rhizoctonia root rot, as determined in seedling assays. Changes in the relative ability of the resident soil microflora to suppress root rot of apple caused by $R$. solani AG 5 were strongly associated with alterations in relative populations of Burkholderia cepacia and the composition of the fluorescent pseudomonad community recovered from apple grown in these soils. Burkholderia cepacia and Pseudomonas putida represented the dominant culturable fraction of total bacteria and fluorescent pseudomonads, respectively, recovered from the rhizosphere of apple seedlings grown in noncultivated orchard soil. Relative rhizosphere populations of Burkholderia cepacia and Pseudomonas putida diminished with increasing age of the orchard block soil in which seedlings were grown. Burkholderia cepacia is antagonistic to both $R$. solani and Pythium spp. and has been used in biological control of diseases caused by these pathogens $(2,11,23)$. Likewise, isolates of Pseudomonas putida recovered from apple seedlings grown in noncultivated WVC-Auvil orchard soils suppressed in vitro growth of $R$. solani and have effectively controlled this pathogen in greenhouse and field trials (20). The results suggest that the reduced ability of the resident microflora to suppress $R$. solani observed at the WVC-Auvil orchard with prolonged cultivation of soil to apple may be due, in part, to reductions in relative populations of Burkholderia cepacia and Pseudomonas putida.

Pseudomonas putida dominated the fluorescent pseudomonad population isolated from the rhizosphere of seedlings grown in noncultivated soil but declined rapidly as a proportion of the total fluorescent pseudomonad population with increasing orchard block age. Several studies have demonstrated the selective influence of plants on the phenotypic and genetic composition of fluorescent pseudomonad populations in the rhizosphere $(7,12,13,25)$. Pseudomonas putida strain 2C8 was isolated from the rhizosphere of apple grown in the greenhouse in noncultivated WVC-Auvil orchard soil. Preliminary growth studies of strain $2 \mathrm{C} 8$ in minimal media with root exudates as the sole carbon source indicate that a 10 -fold higher concentration of 'Gala' apple root exudate is required to achieve the same growth rate as that obtained with root exudate from 'Eltan' wheat (M. Mazzola and Y.-H. Gu, unpublished data). Thus, diminishing populations of Pseudomonas putida in WVC-Auvil orchard soils grown continuously to apple may be due to an inability of the bacterium to efficiently utilize the root exudates of apple.

Based on previous studies $(24,25)$, it is likely that the high frequency of Phl-producing fluorescent pseudomonads observed in soils from the noncultivated portion of the WVC-Auvil orchard was conditioned by long-term cropping of dryland wheat on the site prior to orchard development. Previous studies have demonstrated the ability of Phl-producing fluorescent pseudomonads to suppress soilborne plant diseases, including take-all of wheat (24), black root rot of tobacco (10), and damping-off of sugar beet (6). Genetically enhanced production of $\mathrm{Phl}$ in certain strains of fluorescent Pseudomonas spp. also has resulted in increased suppression of $R$. solani growth in vitro (31). Thus, it is plausible that fluorescent Pseudomonas spp. that produce Phl played a role in the suppressiveness of noncultivated orchard soil to Rhizoctonia root rot of apple. However, Phl-producing fluorescent pseudomonads were almost exclusively limited to the soil population examined in the current study and typically were absent from the fluorescent pseudomonad population recovered from the apple rhizosphere. If in fact Phl-producing fluorescent Pseudomonas spp. contributed to the suppression of $R$. solani observed in previously noncultivated orchard soil, it is likely that suppression occurred during the saprophytic growth phase of the pathogen and not at the site of plant infection. The findings also suggest that the use of a wheat cropping system prior to orchard establishment on replant sites may be a means of enhancing populations of resident antagonists and suppressing one or more components of the fungal complex inciting apple replant disease.

\section{ACKNOWLEDGMENTS}

I thank S. K. Ivanov and E. L. Valdez for excellent technical assistance, the Wenatchee Valley College Pomology Program for use of the Auvil Research and Demonstration Orchard, and D. K. Fujimoto and J. Raaijmakers for critical review of the manuscript.

\section{LITERATURE CITED}

1. Bollard, E. G. 1956. Effect of steam sterilized soil on growth of replant apple trees. N.Z. J. Sci. Technol. 38:412-415.

2. Cartwright, D. K., and Benson, D. M. 1995. Comparison of Pseudomonas species and application techniques for biocontrol of Rhizoctonia stem rot of poinsettia. Plant Dis. 79:309-313.

3. Cook, R. J., and Rovira, A. D. 1976. The role of bacteria in the biological control of Gaeumannomyces graminis by suppressive soils. Soil Biol. Biochem. 8:269-273.

4. Covey, R. P., Jr., Benson, N. R., and Haglund, W. A. 1979. Effect of soil fumigation on the apple replant disease in Washington. Phytopathology 69:684-686.

5. Edel, V., Steinberg, C., Gautheron, N., and Alabouvette, C. 1997. Populations of nonpathogenic Fusarium oxysporum associated with roots of four plant species compared to soilborne populations. Phytopathology 87: 693-697.

6. Fenton, A. M., Stephens, P. M., Crowley, J., O'Callaghan, M., and O'Gara, F. 1992. Exploitation of gene(s) involved in 2,4-diacetylphloroglucinol biosynthesis to confer a new biocontrol capability to a Pseudomonas strain. Appl. Environ. Microbiol. 58:3873-3878.

7. Glandorf, D. C. M., Peters, L. G. L., van der Sluis, I., Bakker, P. A. H. M., and Schippers, B. 1993. Crop specificity of rhizosphere pseudomonads and the involvement of root agglutinins. Soil Biol. Biochem. 25:981-989.

8. Jaffee, B. A., Abawi, G. S., and Mai, W. F. 1982. Role of soil microflora and Pratylenchus penetrans in an apple replant disease. Phytopathology 72:247-251.

9. Jones, A. L., and Aldwinckle, H. S. 1990. Compendium of Apple and Pear Diseases. The American Phytopathological Society, St. Paul, MN.

10. Keel, C., Schnider, U., Maurhofer, M., Voisard, C., Laville, J., Burger, U., Wirthner, P., Haas, D., and Défago, G. 1992. Suppression of root diseases by Pseudomonas fluorescens CHA0: Importance of the bacterial secondary metabolite 2,4-diacetylphloroglucinol. Mol. Plant-Microbe In- 
teract. 5:4-13.

11. King, E. B., and Parke, J. L. 1993. Biocontrol of Aphanomyces root rot and Pythium damping-off by Pseudomonas cepacia AMMD on four pea cultivars. Plant Dis. 77:1185-1188.

12. Latour, X., Corberand, T., Laguerre, G., Allard, F., and Lemanceau, P. 1996. The composition of fluorescent pseudomonad populations associated with roots is influenced by plant and soil type. Appl. Environ. Microbiol. 62: 2449-2456.

13. Lemanceau, P., Corberand, T., Gardan, L., Latour, X., Laguerre, G., Boeufgras, J.-M., and Alabouvette, C. 1995. Effect of plant species, flax (Linum usitatissinum L.) and tomato (Lycopersicon esculentum Mill.), on the diversity of soilborne populations of fluorescent pseudomonads. Appl. Environ. Microbiol. 61:1004-1012.

14. Mahaffee, W. F., and Kloepper, J. W. 1997. Temporal changes in the bacterial communities of soil, rhizosphere, and endorhiza associated with fieldgrown cucumber (Cucumis sativus L.) Microb. Ecol. 34:210-223.

15. Mahaffee, W. F., Kokalis-Burelle, N., Kloepper, J. W., and Rodríguez-Kábana, R. 1996 Effects of peanut-switchgrass rotation on rhizosphere bacterial community structure. (Abstr.) Phytopathology 86 (suppl. 1):S26-S27.

16. Mai, W. F., and Abawi, G. S. 1981. Controlling replant diseases of pome and stone fruits in northeastern United States by preplant fumigation. Plant Dis. 65:859-864

17. Maloney, P. E., van Bruggen, A. H. C., and Hu, S. 1997. Bacterial community structure in relation to the carbon environments in lettuce and tomato rhizospheres and in bulk soil. Microb. Ecol. 34:109-117.

18. Mazzola, M. 1997. Identification and pathogenicity of Rhizoctonia spp. isolated from apple roots and orchard soils. Phytopathology 87:582587.

19. Mazzola, M. 1998. Elucidation of the microbial complex having a causal role in the development of apple replant disease in Washington. Phytopathology 88:930-938.

20. Mazzola, M. 1998. Towards the development of sustainable alternatives for the control of apple replant disease in Washington. Pages 8.1-8.3 in: Proc. Annu. Int. Res. Conf. Methyl Bromide Alternatives and Emissions
Reductions. Methyl Bromide Alternatives Outreach, Fresno, CA.

21. Mazzola, M., and Cook, R. J. 1991. Effects of fungal root pathogens on the population dynamics of biocontrol strains of fluorescent pseudomonads in the wheat rhizosphere. Appl. Environ. Microbiol. 57:2171-2178.

22. Miller, H. J., Henken, G., and Van Veen, J. A. 1989. Variation and composition of bacterial populations in the rhizospheres of maize, wheat, and grass cultivars. Can. J. Microbiol. 35:656-660.

23. Milus, E. A., and Rothrock, C. S. 1997. Efficacy of bacterial seed treatments for controlling Pythium root rot of winter wheat. Plant Dis. 81: 180-184.

24. Raaijmakers, J. M., and Weller, D. M. 1998. Natural plant protection by 2,4-diacetylphloroglucinol-producing Pseudomonas spp. in take-all decline soils. Mol. Plant-Microbe Interact. 11:144-152.

25. Raaijmakers, J. M., Weller, D. M., and Thomashow, L. S. 1997. Frequency of antibiotic-producing Pseudomonas spp. in natural environments. Appl. Environ. Microbiol. 63:881-887.

26. Sewell, G. W. F. 1981. Effects of Pythium species on the growth of apple and their possible causal role in apple replant disease. Ann. Appl. Biol. 97:149-169.

27. Simon, A., and Ridge, E. H. 1974. The use of ampicillin in a simplified selective medium for the isolation of fluorescent pseudomonads. J. Appl. Bacteriol. 37:459-460.

28. Slykhuis, J. T., and Li, T. S. C. 1985. Response of apple seedlings to biocides and phosphate fertilizers in orchard soils in British Columbia. Can. J. Plant Pathol. 7:294-301.

29. Traquair, J. A. 1984. Etiology and control of orchard replant problems: A review. Can. J. Plant Pathol. 6:54-62.

30. Vidaver, A. K. 1967. Synthetic and complex media for the rapid detection of fluorescence of phytopathogenic pseudomonads: Effect of the carbon source. Appl. Microbiol. 15:1523-1524.

31. Vincent, M. A., Harrison, L. A., Brackin, J. M., Kovacevich, P. A., Mukerji, P., Weller, D. M., and Pierson, E. A. 1991. Genetic analysis of the antifungal activity of a soilborne Pseudomonas aureofaciens strain. Appl. Environ. Microbiol. 57:2928-2934. 